\title{
Plant Ecological Studies on Gavi Forests; an Unlogged Tropical Rain Forest Ecosystem, Southern Western Ghats of India.
}

\author{
Abhilash ES
}

Assistant Professor, P.G. Department of Botany, Sree Narayana College, Nattika, Thrissur, Kerala.

\section{Original Article}

\section{Corresponding Author}

Dr. Abhilash ES

Assistant Professor, P.G. Department of Botany

Sree Narayana College

Nattika, Thrissur, India

Email: abhies@gmail.com

\section{Abstract}

Analysis of vegetation of Goodrical Reserve forests shows that unlogged area harbours 65 arborescent species of 590 individuals /ha. On the other hand in logged area, number of species were 54 out of 579 individuals /ha. Simpson and Shannon Weiner indices of unlogged and logged area were $\mathrm{H}^{\prime}-3.08, \mathrm{CD}-0.092$ and $\mathrm{H}^{\prime}-3.60, \mathrm{CD}-0.032$ respectively. This study also shows that high endemism is seen in Goodrical R.F. and species like, Actinodaphne malabarica, Baccaurea courtallensis, Drypetes elata, Cullenia exarillata, Palaquium ellipticum etc. are quite common. Threatened species like, Anacolosa densiflora and Memecylon subramanii are not common in logged area and common in unlogged area. It is quite probable that these species have been extracted extensively during selection felling, till when the selection felling procedure was completely stopped in 1987, and that is why they are absent in logged area.

Key words: Endemics, Species diversity, Threatened species

\section{Introduction}

Tropical Rainforests are the largest treasures of Biodiversity. Tropical forests cover only seven percent of the earth's surface but contain $60-70 \%$ of all living species (Myers, 1988) and among the 34 hot spots in the world two are in India viz. Himalayas and Western Ghats(Huge Synge, 2005). The conservation of genetic diversity of the world is possible only through sustainable maintenance and management of natural ecosystems. Anthropogenic interactions are the biggest cause in forest degradation which later leading to habitat destruction. The current rate of tropical forest loss and disturbances will result in 5-10\% loss of all tropical species per decade over the next quarter century (Mcneely et.al., 1990). The rich and diverse vegetational wealth of India, undoubtedly due to its immensely varying climatic and geographical conditions with varied ecological habitats, is unique. It is therefore essential to have a reasonably fair assessment of floral and faunal components of the biodiversity for optimum utilization of resources. The multifarious human activities are destroying and diminishing earth's carrying capacity to support life that exists on this planet. Today is the outcome of evolutionary process, which is continuing over 5 million years involving speciation, selection and migration and preserve species diversity most effectively. The implementation of proper management plans must preserve the habitats and landscape structure needed by the target species, rather than ex-situ preservation of RET species.

Thus habitat conservation gained importance and we are witnessing areas set aside as National Parks, Wild Life Sanctuaries etc aiming conservation. For effective forest management and bioresource assessment, authentic and scientific studies are essential which include vegetation analysis, habitat identification, restoration of rare and endangered taxa etc. In Ranni Forest Division of Kerala, 32,535 acres of land were under selection felling and as a part of selection felling system, 27 species were identified including Mesua ferrea, Cullenia exarillata, Myristica malabarica etc as potential species for selection felling. The process of selection felling is practiced up to 1987 in Goodrical reserve forests and a number of rare and endangered species might have been felled during these period (Raghavan Nair, 1991). Balasubaramanian (1987) conducted a study which clearly describes that selection felling affects the phenology, dynamics of vegetation, succession etc. Based on this study in 1987, the Kerala Government had imposed a moratorium on selective logging. (Govindan Kutty, 1987).

Plant Ecological studies have a key role in the identification of gene pool and its conservational measures. A study has 
been conducted during the year 2005 to gather information on ecology of plant communities in Gavi forest area, Goodrical R.F, Ranni Forest Division, Kerala with special reference to conservation aspects.

\section{Study area}

Goodrical R.F. lies between $9^{\circ} 10^{\prime}$ to $9^{\circ} 30^{\prime} \mathrm{N}$ latitude and $76^{\circ}$ $55^{\prime}$ to $77^{\circ} 17^{\prime} E$ longitude in Kerala, the hill chains of Western Ghats. Two sites were selected for vegetation studies in the Goodrical R.F. Gavi forest area is unlogged in nature with less human interactions and to compare with this ecosystem another area was selected; Kullar (Selection Felled) area with similar vegetation type. The average annual rainfall received by these areas is $2000-3500 \mathrm{~mm}$ with high precipitation during both the South-west and the North-east monsoons with maximum rainfall in July and minimum during January. These hills belong to the crystalline rocks of Arachean age, comprising chiefly charnokites with narrow bands of Pyroxene granulites and Magnetite quartz (GSI, 1976). The soil is an oxisol, with high contents of iron, aluminium and manganese and with low contents of calcium and magnesium. Based on Chandrasekharan (1962) and Champion and Seth (1968), the vegetation of the area fall under West Coast Tropical Evergreen Forests.

\section{Material and Methods}

Stratified random sampling method was adopted for the present study. Ten, 0.1 ha quadrats were established in the two study sites. In each quadrat the tree species having $>30.1$ $\mathrm{cm} \mathrm{GBH}$ (girth at breast height) were measured and recorded (Chandrasekhara, 1998). In order to express dominance and ecological success of any species, the Importance value index (IVI) was worked out (Curtis and McIntosh, 1950). The ratio of abundance to frequency ( $A B / F)$ was also worked out to interpret the distribution pattern of the species. The values are used for categorizing the nature of distribution as, regular (<. 025), random (0.025 to 0.05), and contagious (>0.05) distribution (Curtis and Cottom 1956). Species diversity is one of the most important characteristic of a community and this was determined as per Shannon and Wiener (1963). Species dominance values were measured by following Simpson's Index (1949).

Law of frequency for homogeneity was according to Raunkier (1934), where percentage frequency values from all transects were grouped into five frequency classes and values were tested using the formula $A>B>C<=>D>E$.

In order to find out the girth class distribution pattern, enumerated trees were grouped into different classes viz. D1 (30-59.9), D2 (60-89.9), D3 (90-119.9), D4 (120-149.9), D5 (150-179.9) and D6 (>180) according to their girth at breast height.

\section{Results and Discussion:}

In Gavi, 65 arborescent species belongs to 590 individuals were recorded from one-hectare area (Table-1.) and the most
Table .1- Structural Analysis of Gavi forest area

\begin{tabular}{|c|c|c|c|c|c|}
\hline Species & D & $\mathbf{F}$ & BA & IVI & $\mathrm{AB} / \mathrm{F}$ \\
\hline Acronychia pedunculata & 150.00 & 40.00 & 232.53 & 5.32 & 0.094 \\
\hline Actinodaphne campanulata & 10.00 & 10.00 & 240.63 & 1.25 & 0.100 \\
\hline Actinodaphne malabarica & 30.00 & 20.00 & 312.38 & 2.31 & 0.075 \\
\hline Agrostistachys borneensis & 1390.00 & 80.00 & 253.70 & 28.67 & 0.217 \\
\hline Alseodaphne semecarpifolia & 70.00 & 40.00 & 602.08 & 4.74 & 0.044 \\
\hline Anacolosa densiflora & 20.00 & 10.00 & 588.32 & 2.15 & 0.200 \\
\hline Antiaris toxicaria & 80.00 & 50.00 & 2785.34 & 10.08 & 0.032 \\
\hline Antidesma menasu & 70.00 & 40.00 & 130.94 & 3.75 & 0.044 \\
\hline Aphanamixis polystachya & 20.00 & 10.00 & 121.92 & 1.17 & 0.200 \\
\hline Aporusa lindleyana & 10.00 & 10.00 & 276.90 & 1.32 & 0.100 \\
\hline Artocarpus heterophyllus & 10.00 & 10.00 & 1718.90 & 4.36 & 0.100 \\
\hline Bhesa indica & 160.00 & 30.00 & 551.29 & 5.59 & 0.178 \\
\hline Calophyllum polyanthum & 10.00 & 10.00 & 673.27 & 2.16 & 0.100 \\
\hline Canarium strictum & 10.00 & 10.00 & 4971.59 & 11.22 & 0.100 \\
\hline Canthium rheedi & 30.00 & 20.00 & 178.22 & 2.03 & 0.075 \\
\hline Cedrella toona & 150.00 & 80.00 & 295.99 & 7.74 & 0.023 \\
\hline Cinnamomum keralense & 10.00 & 10.00 & 658.72 & 2.13 & 0.100 \\
\hline Cinnamomum malabatrum & 20.00 & 20.00 & 78.93 & 1.65 & 0.050 \\
\hline Clausena indica & 10.00 & 10.00 & 97.44 & 0.95 & 0.100 \\
\hline Cryptocarya anamalayana & 10.00 & 10.00 & 161.08 & 1.08 & 0.100 \\
\hline Cullenia exarillata & 530.00 & 100.00 & 2396.32 & 19.75 & 0.053 \\
\hline Dimocarpus longan & 120.00 & 50.00 & 358.86 & 5.65 & 0.048 \\
\hline Dimorphocalyx lawianus & 10.00 & 10.00 & 389.77 & 1.56 & 0.100 \\
\hline Diospyros bourdillonii & 20.00 & 10.00 & 100.25 & 1.12 & 0.200 \\
\hline Diospyros candolleana & 50.00 & 30.00 & 445.06 & 3.50 & 0.056 \\
\hline Diospyros paniculata & 10.00 & 10.00 & 717.90 & 2.25 & 0.100 \\
\hline Dysoxylum malabaricum & 60.00 & 30.00 & 2070.44 & 7.09 & 0.067 \\
\hline Drypetes elata & 430.00 & 100.00 & 722.47 & 14.53 & 0.043 \\
\hline Elaeocarpus serratus & 110.00 & 20.00 & 186.06 & 3.40 & 0.275 \\
\hline Filicium decipiens & 10.00 & 10.00 & 2548.72 & 6.11 & 0.100 \\
\hline Garcinia gummi-gutta & 40.00 & 10.00 & 127.27 & 1.52 & 0.400 \\
\hline Garcinia morella & 140.00 & 60.00 & 276.90 & 6.39 & 0.039 \\
\hline Gomphandra coriacea & 120.00 & 50.00 & 220.99 & 5.36 & 0.048 \\
\hline Gordonia obtusa & 10.00 & 10.00 & 3676.99 & 8.49 & 0.100 \\
\hline Gouania microcarpa & 10.00 & 10.00 & 76.44 & 0.90 & 0.100 \\
\hline Heritiera papilio & 10.00 & 10.00 & 2218.44 & 5.42 & 0.100 \\
\hline Holigarna arnottiana & 10.00 & 10.00 & 1164.63 & 3.20 & 0.100 \\
\hline Holigarna beddomei & 10.00 & 10.00 & 305.77 & 1.39 & 0.100 \\
\hline Hydnocarpus pentandra & 10.00 & 10.00 & 423.90 & 1.63 & 0.100 \\
\hline Knema attenuata & 120.00 & 70.00 & 812.78 & 7.75 & 0.024 \\
\hline Litsea ligustrina & 50.00 & 30.00 & 1090.76 & 4.86 & 0.056 \\
\hline Litsea oleoides & 30.00 & 30.00 & 683.07 & 3.66 & 0.033 \\
\hline
\end{tabular}

Asia Pacific Journal of Environment Ecology and Sustainable Development 2013;1:15-21

(An International Peer Reviewed Journal)Copyright (C) 2013 ATRFCE

Published online by NepJOL-INASP

www.nepjolinfo/index.php/APJEESD 


\begin{tabular}{|c|c|c|c|c|c|}
\hline Species & D & $\mathbf{F}$ & BA & IVI & $A B / F$ \\
\hline Macaranga peltata & 30.00 & 20.00 & 375.07 & 2.44 & 0.075 \\
\hline Mallotus tetracoccus & 10.00 & 10.00 & 1789.77 & 4.51 & 0.100 \\
\hline Mastixia arborea & 30.00 & 10.00 & 140.32 & 1.38 & 0.300 \\
\hline Meiogyne pannosa & 80.00 & 10.00 & 103.81 & 2.15 & 0.800 \\
\hline Meliosma simplicifolia & 10.00 & 10.00 & 154.00 & 1.07 & 0.100 \\
\hline Memecylon deccanense & 20.00 & 20.00 & 157.52 & 1.81 & 0.050 \\
\hline Memecylon subramanii & 10.00 & 10.00 & 77.43 & 0.90 & 0.100 \\
\hline Memecylon umbellatum & 40.00 & 20.00 & 196.88 & 2.24 & 0.100 \\
\hline Mesua ferrea & 100.00 & 50.00 & 1254.86 & 7.20 & 0.040 \\
\hline Mesua thwaitesii & 50.00 & 40.00 & 361.36 & 3.89 & 0.031 \\
\hline Myristica dactyloides & 10.00 & 10.00 & 127.27 & 1.01 & 0.100 \\
\hline Myristica malabarica & 30.00 & 20.00 & 625.37 & 2.97 & 0.075 \\
\hline Neolitsea $s p$ & 10.00 & 10.00 & 81.45 & 0.91 & 0.100 \\
\hline Ostodes zeylanicus & 10.00 & 10.00 & 346.50 & 1.47 & 0.100 \\
\hline Otonephilium stipulaceum & 40.00 & 20.00 & 612.50 & 3.11 & 0.100 \\
\hline Palaquium ellipticum & 740.00 & 100.00 & 1102.52 & 20.58 & 0.074 \\
\hline Schleichera oleosa & 300.00 & 60.00 & 301.35 & 9.15 & 0.083 \\
\hline Syzygium gardneri & 60.00 & 30.00 & 1132.76 & 5.12 & 0.067 \\
\hline Syzygium laetum & 40.00 & 30.00 & 173.85 & 2.76 & 0.044 \\
\hline Syzygium munronii & 10.00 & 10.00 & 81.45 & 0.91 & 0.100 \\
\hline Turpinia malabarica & 10.00 & 10.00 & 1145.45 & 3.15 & 0.100 \\
\hline Trichilia connaroides & 20.00 & 10.00 & 103.09 & 1.13 & 0.200 \\
\hline Vateria indica & 60.00 & 30.00 & 1061.16 & 4.97 & 0.067 \\
\hline Total & 5900.00 & 1750.00 & 47449.71 & 300.00 & 7.180 \\
\hline
\end{tabular}

D-Density, F-Frequency, BA-Basal area, AB-Abundance,

IVI-Importance Value Index.

dominant species in top canopy, based on IVI (value in parenthesis), are Agrostistachys borneensis (28.67) followed by Palaquium ellipticum (20.58), Cullenia exarillata. (19.75) and Drypetes elata (14.53). The study site Kullar harbours 54 species out of 579 individuals/ hectare (Table-2.) The most

Table .2- Structural Analysis of Kullar forest area

\begin{tabular}{|l|r|r|r|rr|}
\hline Species & \multicolumn{1}{|c|}{ D } & F & BA & IVI & AB/F \\
\hline Actinodaphne campanulata & 120.00 & 30.00 & 736.91 & 4.66 & 0.130 \\
\hline Aglaia lawii & 240.00 & 50.00 & 178.22 & 6.65 & 0.100 \\
\hline Alstonia scholaris & 30.00 & 30.00 & 97.44 & 2.00 & 0.030 \\
\hline Apodytes dimidiata & 30.00 & 30.00 & 114.86 & 2.03 & 0.030 \\
\hline Aporusa lindleyana & 220.00 & 80.00 & 103.61 & 7.49 & 0.030 \\
\hline Artocarpus hirsutus & 30.00 & 30.00 & 11913.44 & 22.41 & 0.030 \\
\hline Atalantia racemosa & 410.00 & 50.00 & 117.83 & 9.48 & 0.160 \\
\hline Baccaurea courtallensis & 260.00 & 100.00 & 149.99 & 9.14 & 0.030 \\
\hline Cedrela toona & 80.00 & 50.00 & 583.20 & 4.58 & 0.030 \\
\hline
\end{tabular}

\begin{tabular}{|c|c|c|c|c|c|}
\hline Species & D & $\mathbf{F}$ & BA & IVI & $A B / F$ \\
\hline Cinnamomum keralense & 30.00 & 30.00 & 86.63 & 1.98 & 0.03 \\
\hline Cinnamomum $r$ & 20.00 & 20.00 & 190.99 & 1.55 & 0.0 \\
\hline Clerodendrum viscosum & 30.00 & 30.00 & 161.08 & 2.11 & 0.030 \\
\hline Croton malabaricus & 30.00 & 30.00 & 114.86 & 2.03 & 0.030 \\
\hline Dillenia pentagyna & 30.00 & 30.00 & 81.45 & 1.97 & 0.030 \\
\hline Diospyros paniculata & 270.00 & 50.00 & 621.72 & 7.93 & 0.110 \\
\hline Dipterocarpus bourdillonii & 30.00 & 30.00 & 267.59 & 2.30 & 0.030 \\
\hline Drypetes elata & 90.00 & 30.00 & 517.61 & 3.76 & 0.100 \\
\hline Dysoxylum malabaricum & 290.00 & 70.00 & 1282.99 & 10.30 & 0.060 \\
\hline Elaeocarpus tuberculatus & 110.00 & 50.00 & 1306.98 & 6.35 & 0.040 \\
\hline Flacourtia montana & 90.00 & 30.00 & 286.36 & 3.36 & 0.100 \\
\hline Garcinia gummi-gutta & 210.00 & 30.00 & 462.92 & 5.74 & 0.230 \\
\hline Garcinia morella & 20.00 & 20.00 & 223.44 & 1.61 & 0.050 \\
\hline Heritiera papilio & 30.00 & 30.00 & 183.27 & 2.15 & 0.030 \\
\hline Holigarna arnottiana & 30.00 & 30.00 & 1386.00 & 4.23 & 0.030 \\
\hline Holigarna nigra & 30.00 & 30.00 & 367.82 & 2.47 & 0.030 \\
\hline Hopea parviflora & 30.00 & 30.00 & 13371.59 & 24.93 & 0.030 \\
\hline Hopea racophloea & 20.00 & 20.00 & 127.27 & 1.44 & 0.050 \\
\hline 1 & 0 & 00 & 11.58 & 9.06 & 0.050 \\
\hline Ixora brachiata & 160.00 & 20.00 & 159.29 & 3.92 & 0.400 \\
\hline Knema attenuata & 230.00 & 80.00 & 729.77 & 8.74 & 0.040 \\
\hline Leea indica & 60.00 & 40.00 & 88.38 & 2.94 & 0.040 \\
\hline Lepisanthes erecta & 60.00 & 30.00 & 305.77 & 2.88 & 0.070 \\
\hline Lophopetalum wight & 40.00 & 40.00 & 673.27 & 3.61 & 0.030 \\
\hline Maca & 50.00 & 30.00 & 32 & 5.02 & 0.170 \\
\hline Mallo & 0.00 & 100.00 & 385.01 & 8.68 & 0.020 \\
\hline Mallotus tetracocc & 0.00 & 30.00 & 86 & 2.03 & 0.030 \\
\hline Myristica dactyloides & 50.00 & 50.00 & 363.50 & 3.68 & 0.020 \\
\hline Myristica malabarica & 40.00 & 20.00 & 1024.72 & 3.34 & 0.100 \\
\hline Nothopegia colebr & 20.00 & 20.00 & 876.99 & 2.74 & 0.050 \\
\hline Olea dioica & 90.00 & 30.00 & 101.19 & 3.04 & 0.100 \\
\hline Oton & 10.00 & 00 & 11 & 4.47 & 0.040 \\
\hline Polyal & 310.00 & 100.00 & 342.78 & 10.33 & 0.030 \\
\hline Schleichera oleosa & 60.00 & 30.00 & 179.47 & 2.66 & 0.070 \\
\hline Strombosea zeylanica & 240.00 & 70.00 & 633.03 & 8.31 & 0.050 \\
\hline Strychnos nuxvomica & 40.00 & 20.00 & 187.11 & 1.89 & 0.100 \\
\hline Symplocos $r$ & 50.00 & 50.00 & 122.23 & 3.27 & 0.020 \\
\hline Syzygium elatum & 30.00 & 30.00 & 215.09 & 2.21 & 0.030 \\
\hline Termi & 40.00 & 20.00 & 3040.25 & 6.82 & 0.100 \\
\hline Tetrameles nudiflora & 50.00 & 50.00 & 1550.19 & 5.73 & 0.020 \\
\hline Turpinia malabarica & 240.00 & 80.00 & 567.41 & 8.63 & 0.040 \\
\hline Vateria indica & 240.00 & 50.00 & 803.43 & 7.73 & 0.100 \\
\hline Vitex & 30 & 30 & בכטנ & 17.44 & 0.0 \\
\hline Xanthophyllum ar & 90.00 & 70.00 & 95.60 & 4.79 & 0.0 \\
\hline Zanthoxylum rhetsa & 20.00 & 20.00 & 86.63 & 1.37 & 0.050 \\
\hline Total & 5790.00 & 2280.00 & 57890.01 & 300.00 & 3.48 \\
\hline
\end{tabular}

Asia Pacific Journal of Environment Ecology and Sustainable Development 2013;1:15-21 (An International Peer Reviewed Journal)Copyright (C) 2013 ATRFCE Published online by NepJOL-INASP www.nepjolinfo/index.php/APJEESD 
dominant species are Hopea parviflora.(24.93), followed by Artocarpus hirsutus (22.41) and Vitex altissima. (17.44). It is evident from the study that eventhough species density wise there is not much differences from logged and unlogged localities, selection felling and its impacts made changes in species composition (Table 1\&2).

Basal area refers to the ground, actually occupied by the stems, and is one of the chief character that determine the dominance. Maximum basal area at the Gavi was shown by Canarium strictum $\left(4971.59 \mathrm{~cm}^{2} / \mathrm{ha}\right.$ ) and Gordonia obtusa $\left(3676.99 \mathrm{~cm}^{2} / \mathrm{ha}\right)$ respectively (Table-1.) where as, in Kullar location maximum basal area was recorded with Hopea parviflora (13371.5959 $\left.\mathrm{cm}^{2} / \mathrm{ha}\right)$, Artocarpus hirsutus $\left(11913.44 \mathrm{~cm}^{2} / \mathrm{ha}\right)$ and Vitex altissima $\left(9033.90 \mathrm{~cm}^{2} / \mathrm{ha}\right)$ (Table-2.).

Percentage Frequency denotes, occurrence of a given species in the sample plots. In Gavi, Palaquium ellipticum, Cullenia exarillata, Cedrela toona, Drypetes elata etc. are the most frequent species (Table-1), whereas in Kullar, Baccaurea courtallensis ,Mallotus philippensis, Polyalthia fragrans etc. showed more frequency (Table.2). Floristic studies have also resulted in locating an, endangered and endemic plant, Anacolosa densiflora, and was reported only from two places and considered to be endangered (Table.3).

\section{Table 3. Status of conservational categories}

\begin{tabular}{|c|c|c|c|}
\hline Endemicspecies & $\begin{array}{c}\text { Number In } \\
\text { Gavi }\end{array}$ & $\begin{array}{l}\text { Number In } \\
\text { Kullar }\end{array}$ & Remarks \\
\hline Actinodaphne campanulata & 0 & 12 & Rare \\
\hline Actinodaphne malabarica & 1 & 0 & Rare \\
\hline Anacolosa densiflora & 2 & 0 & Endangered \\
\hline Artocarpus hirsutus & 0 & 3 & \\
\hline Cinnamomum keralense & 1 & 3 & \\
\hline Cinnamomum malabatrum & 2 & 2 & \\
\hline Cryptocarya anamalayana & 1 & 0 & Endangered \\
\hline Cullenia exarillata & 53 & 0 & \\
\hline Diospyros bourdillonii & 2 & 0 & $\begin{array}{c}\text { Critically } \\
\text { endangered }\end{array}$ \\
\hline Diospyros paniculata & 1 & 27 & \\
\hline Drypetes elata & 43 & 9 & Rare \\
\hline Dysoxylum malabaricum & 6 & 29 & \\
\hline Gordonia obtusa & 1 & 0 & \\
\hline Holigarna arnottiana & 1 & 3 & \\
\hline Holigarna beddomei & 1 & 0 & Vulnerable \\
\hline Holigarna nigra & 0 & 3 & Rare \\
\hline
\end{tabular}

\begin{tabular}{|c|c|c|c|}
\hline Endemicspecies & $\begin{array}{c}\text { Number In } \\
\text { Gavi }\end{array}$ & $\begin{array}{l}\text { Number In } \\
\text { Kullar }\end{array}$ & Remarks \\
\hline Hydnocarpus pentandra & 0 & 29 & \\
\hline Knema attenuata & 12 & 23 & \\
\hline Litsea ligustrina & 1 & 0 & Vulnerable \\
\hline Memecylon deccanense & 2 & 0 & \\
\hline Memecylon subramanii & 1 & 0 & $\begin{array}{c}\text { Rare, } \\
\text { Endangered }\end{array}$ \\
\hline Myristica malabarica & 1 & 4 & Vulnerable \\
\hline Nothopegia colebrookeana & 0 & 2 & \\
\hline Palaquium ellipticum & 74 & 0 & \\
\hline Polyalthia fragrans & 0 & 31 & \\
\hline Symplocos rosea & 0 & 5 & \\
\hline Syzygium laetum & 4 & 3 & \\
\hline Turpinia malabarica & 1 & 24 & \\
\hline Total & 160 & 204 & \\
\hline
\end{tabular}

Regarding the distribution pattern, the Gavi study area was characterised by preponderance of contagious distribution ( 50 species) and the rarity of regular species ( 2 species), as it is evident from the ratio of abundance to frequency. All others show random distribution (in total, 13 species) (Table-4).

At Kullar area, random distribution is more, with 32 species, followed by 17 contagious. Five species are regular distribution (Table-4).

\section{Table 4. Distribution pattern.}

\begin{tabular}{|l|c|c|c|c|c|}
\hline TYPE & CATEGORY & LOCALITY & REGULAR & RANDOM & CONTAGIOUS \\
\hline EVERGREEN & Trees & GAVI & 3.13 & 20.31 & 76.56 \\
\hline EVERGREEN & Trees & KULLAR & 9.26 & 59.26 & 31.48 \\
\hline
\end{tabular}

According to Odum (1971) contagious distribution is the most commonest pattern in nature, random distribution occurring in the uniform environments, and regular distribution in areas where severe competition between individuals exists.

As expected, Kullar shows less species richness (R1-8.33) than Gavi (R1-10.03) (Table-5). The species diversity ( $\left.H^{\prime}\right)$ was more in Kullar (3.60), as compared to Gavi (3.08), because the logged area will have more number of species due to canopy break and thereby establishment of light demanding species. Thus the pioneer species of the forest type was changed gradually to secondary species, ultimately changing the species composition. It was also observed that the dominance (CD) was more in Gavi (0.092) than (0.032) - (Table-5).

Asia Pacific Journal of Environment Ecology and Sustainable Development 2013;1:15-21

(An International Peer Reviewed Journal)Copyright (C) 2013 ATRFCE

Published online by NepJOL-INASP

www.nepjolinfo/index.php/APJEESD 
Table 5. Biodiversity Indices

\begin{tabular}{|l|c|c|c|}
\hline Sites & $\begin{array}{l}\text { Shannon's } \\
\text { Species } \\
\text { Diversity(H') }\end{array}$ & $\begin{array}{l}\text { Simpson's } \\
\text { Dominance (CD) }\end{array}$ & $\begin{array}{l}\text { Margaleff's } \\
\text { speciesrichness } \\
\text { (R1) }\end{array}$ \\
\hline Gavi & 3.08 & 0.092 & 10.03 \\
\hline Kullar & 3.60 & 0.032 & 8.33 \\
\hline Gavi & 3.08 & 0.092 & 10.03 \\
\hline
\end{tabular}

The nature of distribution was worked out and based on the study of frequency classes, both of the study areas showed heterogenous type of distribution (Table.6).

Table-6. Frequency classes evergreen forests

\begin{tabular}{|l|c|c|c|c|c|c|}
\hline LOCALITY & $\begin{array}{c}\text { A } \\
(\mathbf{0 - 2 0})\end{array}$ & $\begin{array}{c}\text { B } \\
(\mathbf{2 1 - 4 0 )}\end{array}$ & $\begin{array}{c}\text { C } \\
(\mathbf{4 1 - 6 0 )}\end{array}$ & $\begin{array}{c}\text { D } \\
\mathbf{( 6 1 - 8 0 )}\end{array}$ & $\begin{array}{c}\text { E } \\
(\mathbf{8 1 - 1 0 0 )}\end{array}$ & NATURE \\
\hline GAVI & 41 & 12 & 6 & 3 & 3 & $\begin{array}{c}\text { HETERO } \\
\text { GENOUS }\end{array}$ \\
NILAKKAL & 9 & 25 & 10 & 6 & 3 & $\begin{array}{c}\text { HETERO } \\
\text { GENOUS }\end{array}$ \\
\hline
\end{tabular}

' $\mathrm{L}$ ' shaped curve of girth class distribution indicates that the forest was undisturbed (Menon and Balasubramanian, 2006). The girth class distribution curve of Gavi showed the nature of undisturbed forest, as it was actually an unlogged forest ecosystem

In one of the previous study, Menon and Balasubramanian (2006) obtained 106 species of saplings/ha and 119 species of seedlings/ha from selection felled area of West coast tropical evergreen forests of Goodrical range. The non selection felled area showed the presence of 34 species of saplings/ha and $46 /$ ha species of seedlings for West coast tropical evergreen forests. This shows that in the selection felled areas, the succession is still going on and unlogged areas it is almost saturated due to climax nature of forest species. (Fig.1 and Fig.2).

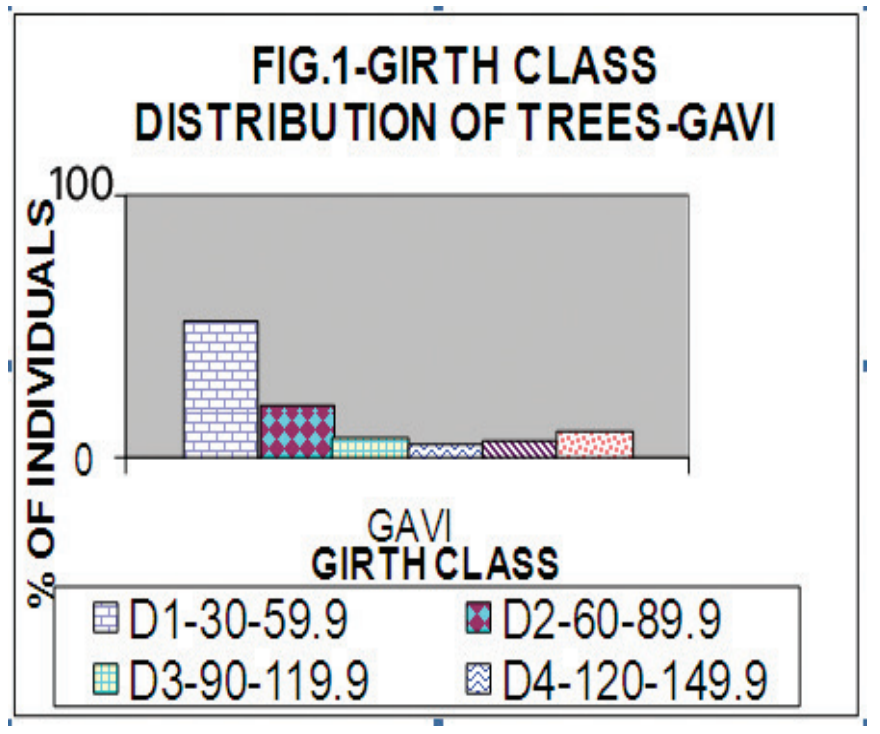

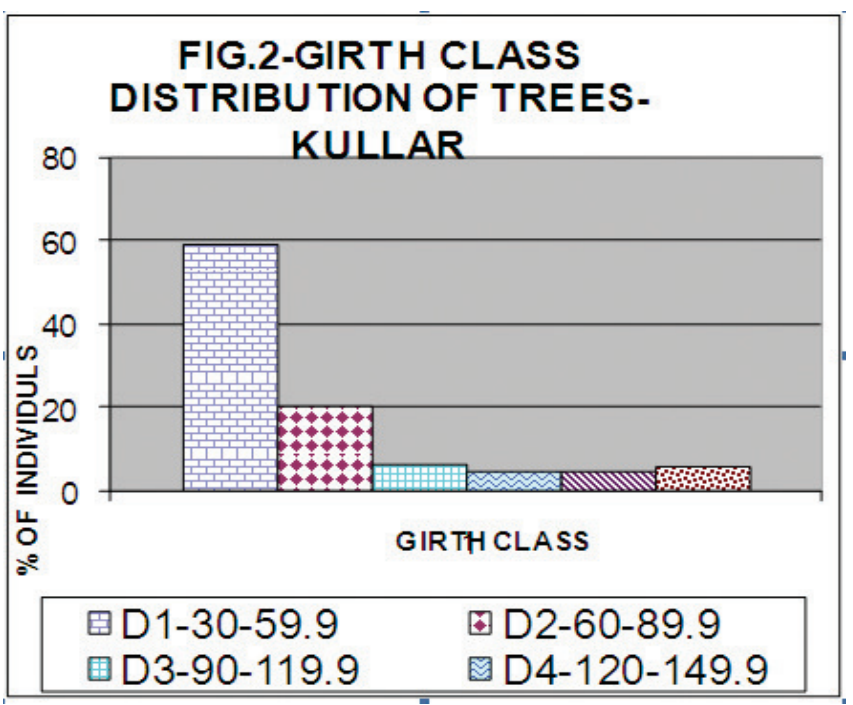

The endemic species in the flora of a geographical region, represent the biogeography of the area, centre of speciation and adaptive evolution (Nayar, 1996 and 1997). There are 1,923 taxa of flowering plants, endemic to Peninsular India (Ahmedullah and Nayar, 1987). Among the estimated 4,679 species of flowering plants in Kerala, 1637 are endemic to the Southern Western Ghats; of which 263 are reported to occur only in Kerala (Sasidharan, 2004). Nayar (1997) prepared a list of endemic plants in the study area, along the lines of IUCN (2000)- (Table-5) and the individual percentage of endemics and Rare Endangered and Threatened species were calculated. The vegetation study in Gavi area showed that out of $38.64 \%$ of total individuals represented, endemics in the category of rare, endangered and threatened are of $2.88 \%$, and for for Kullar it was 5.01\%, among $41.45 \%$ of total individuals represented (Table-5). The emergence of light demanding species is an indicator of canopy openings and forest degradation in tropical evergreen forests. The percentage representation of secondary species was $0.51 \%$ of individuals in Gavi and $11.57 \%$ of individuals in Kullar. Thus, the logged area of Kullar exhibits much higher numbers of secondary species and there by confirming its degraded nature.

\section{Conclusion:}

This study evaluates the Phytosociological aspects of Gavi forest area and the interrelationship of the tree species. Palaquium ellipticum and Cullenia exarillata association was observed at evergreen forest type of Gavi area, whereas in Kullar, Hopea parviflora and Artocarpus hirsutus association was observed.

In the case of species richness and diversity, the trend is reverse, as exemplified by the Shannon and Simpson Index. As a general rule in unlogged areas, the girth class normally follows ' $L$ ' shaped curve. This is true, in the case of Gavi area which is pristine in nature. In the selection felled areas this pattern is not encountered, and the curve shows ups and down.

Asia Pacific Journal of Environment Ecology and Sustainable Development 2013;1:15-21

(An International Peer Reviewed Journal)Copyright (C) 2013 ATRFCE

Published online by NepJOL-INASP

www.nepjol.info/index.php/APJEESD 
The study also reveals the distribution pattern of the species. Contagious distribution is more in Gavi, which is the commonest pattern in nature. The majority of plant species shows random distribution in Kullar site. The floristic study shows that the study area harbours a large number of endemic plants and other categories of conservation importance viz. endangered, rare, vulnerable plants etc. As expected, the logged area housed more number of secondary species than the unlogged ones, and this could be because of the emergence of light demanding species in logged areas and thereby suppressing the growth of primary shade loving species. Normally in logged forest, species like Macaranga peltate, Clerodendrum viscosum, Leea sp. etc. are found at the expense of other shade loving species.

The percentage of secondary species observed in unlogged area was $0.51 \%$ as against logged area, where it was $11.57 \%$, indicating the change in species composition in selection felled area. From this it can be inferred that in Goodrical area, even after selection felling, vegetation has recouped in better way with respect to structural status, may be due to inaccessibility, rugged and hilly terrain nature and low anthropogenic influence; but species composition has changed to secondary species from primary species.

The study also reveals that species diversity and species richness are more in logged areas as against pristine ones due to the fact that pristine forests are of climax type.

\section{Acknowledgments:}

The author is extremely thankful to Director KFRI for excellent support and Kerala State Forest Department for Financial assistance.

\section{References:}

Ahmedullah, M. and M.P.Nayar.1987.Endemic Plants of the Indian Region.Botanical Survey of India, Calcutta. Burgess Publishing Co.Minnisota.193p.

Balasubramanian, K. 1987. Impact of Selection felling in forest ecosystem in Kerala. A study sponsored by the Ministry of Environment and Forests, Govt. of India, New Delhi.65p.

Champion, H.G. and S.K. Seth, 1968.A revised Survey of Forest Types of India. Manager of Publications, New Delhi, 404p.

Chandrasekhara, U.M. 1998. Evaluating Plant diversity in different forest types by laying out permanent sample plots. KFRI Research report No: 156.Kerala Forest Research Institute, Peechi, Kerala. 88p.

Chandrasekharan, C. 1962. Forest Types of Kerala State (1). Indian For.88: 660-674
Curtis, J.T. and G.Cottam 1956. Plant Ecology Work Book. Laboratory field reference manual.

Curtis, J.T.and R.P. Maclntosh 1950 . The Interrelations of certain analytic and synthetic phytosociological characters. Ecology 31:434-455

Govindan Kutty,M.1987.Forest Management - A retrospect. Natural resources of India (Balachandran Thampi, K.Nayar, N.M and Nair,C.S., ed.) Worldwide fund for Nature- India. Kerala State Office, Trivandrum, P. 460-466

GSI, 1976.Geology and Mineral resources of the states of India. Part IX. Kerala. Miscellaneous publication No.30.Geological Survey of India, Govt.of India.

Huge Synge, 2005. Plant Talk 40:33-36.2005

Mc Neely, J, A., K.R. Miller, W.V. Reid, R.A. Mittermeir and T.B. Werner 1990. Conserving the world Biological Diversity. IUCN, Gland, Switzerland.193P

Myers, N., 1988.Threatened biota: "hot spots" in tropical forest. The Environmentalist,8.1-20

Menon, A.R.R and K. Balasubramanian. 2006. Evaluation of plant diversity in unlogged and logged stands of varying intensities. Kerala Forest Research Institute, Research Report No.281. 126pp.

Nayar, M.P.1997. Biodiversity challenges in Kerala and Science of Conservation biology.In:P.Puspangadan and K.S.S.Nair(Eds).Biodiversity of Tropical Forests the Kerala Scenario,STEC,Kerala,Trivandrum.. 7-80.

Nayar, M.P.1996. Hot Spots of Endemic Plants of India, Nepal and Bhutan.Tropical Botanic Garden and Research Institute, Trivandrum.252p.

Odum, E.P., 1971. Fundamentals of Ecology.W.B.Saunders.Co., Philadelphia, 574p.

Raghavan Nair, 1991. Podocarpus Vallichiana (Presl). Proc. Symp. rare endangered and endemic plants. Kerala Forest Department, Trivandrum. pp. 70-71.

Raunkier, C., 1934.The life forms of plants and statistical plant geography. Clareendron Press. Oxford, 632p.

Sasidharan, N. 2004. Biodiversity Documentation for Kerala, Part 6: Flowering Plants. KFRI Handbook No. 17. Kerala Forest Research.Institute, Peechi.702 pp.

Shannon, C.E and W.Weiner, 1963. The mathematical theory of communication. Urbana, Uni, Illinois press.117p. 
Simpson,E.H., 1949. Measurement of Diversity, Nature, 163-688.

\section{Article Information}

\section{Article history}

Received

Received in revised form

Accepted
21 October 2012

21 November 2012

2 December 2012 